Persp. Teol. 41 (2009) 211-231

\title{
O DESAFIO DO AGNOSTICISMO
}

\section{(The challenge of agnosticism)}

\author{
Mario de França Miranda SJ *
}

RESUMO: O artigo constitui uma reflexão sobre a problemática atual sobre Deus, mais precisamente sobre o acesso a Deus. Inicialmente são examinadas algumas razões para certo agnosticismo presente, sobretudo no meio acadêmico. Em seguida o texto aborda a fragmentação da razão clássica numa pluralidade de "racionalidades" que acabam por condicionar o conhecimento humano (horizontes de compreensão) e, consequentemente, seu acesso ao Transcendente. A terceira parte do artigo propugna uma maior unidade de fé e razão, de teologia e filosofia e busca recuperar a verdade da clássica teologia negativa ou apofática. Finalmente, a partir de uma teologia da criação e numa perspectiva agostiniana, se defende o acesso existencial a Deus, que deveria ser mais valorizado na teologia e na pastoral.

PalAVRAS-CHAVE: Acesso a Deus, Agnosticismo, Fé e razão, Teologia apofática, Agostinho.

ABSTRACT: This article is a reflection on the present-day issue of God, more precisely concerning access to God. First there is an examination of a number of reasons for a certain current agnosticism, especially in academic circles. This is followed by a discussion of the fragmentation of classical reason in a plurality of "reasoning" which end up by conditioning human knowledge (horizons of comprehension) and consequently its access to the transcendent. The third part of this article argues for a greater unity between faith and reason, between theology and philosophy and seeks to recover the truth of classical negative or apophatic theology. Finally, through a Trinitarian theology of the creation and from an

\footnotetext{
* Departamento de Teologia da PUC - Rio de Janeiro. Artigo submetido a avaliação no dia 07/11/2008 e aprovado para publicação no dia 21/12/2008.
} 
Augustinian perspective, the author defends an existential access to God, to which greater importance ought to be attached in theology and in pastoral work.

KEY-WORDS: Access to God, Agnosticism, Faith and reason, Apophatic theology, Augustine.

— sta reflexão se originou de uma constatação que sempre me questionou número significativo de professores que se declaram agnósticos com relação à fé em Deus. Muitos deles vivem com coerência os valores éticos do próprio cristianismo, alguns mesmo mais seriamente do que muitos católicos. Não se pode apontar uma área acadêmica determinada onde eles se concentrariam, pois estão em quase todas elas, como engenharia, física, química, filosofia, psicologia, história, sociologia, economia, só para citar algumas. Eles vivem, de fato, um agnosticismo prático, mas decorrente de um agnosticismo teórico.

O fato em si pede uma reflexão. Pois o mundo acadêmico, por dispor de maior conhecimento, é também o setor mais crítico da sociedade. Ele pode estar a sinalizar um problema que deveria ser enfrentado, já que poderá emergir em outras áreas da sociedade situadas fora da Universidade. De fato, assistimos hoje a um fato inédito na história da humanidade. Qualquer cidadão pode viver tranquilamente sem aderir a qualquer religião, apanágio no passado apenas de uma pequena classe pensante mais crítica.

Naturalmente esta questão é bem mais complexa e extrapola uma simples experiência pessoal feita num campus universitário. Num mundo que sofre transformações sucessivas e aceleradas, como falar de Deus? Numa sociedade globalizada constituída por múltiplas culturas e crenças religiosas, como anunciar o Deus de Jesus Cristo? Num mundo secularizado que anseia por justiça e paz no planeta e que confina ao âmbito pessoal a fé religiosa, como proclamar um Deus presente e atuante na história concreta da humanidade?

Os verbos acima mencionados já denotam que a nossa questão não se limita somente à existência de Deus, mas também de como proclamá-lo aos nossos contemporâneos. Pois a crença em Deus só existe no interior de uma tradição cultural, onde ela se expressa, se atualiza, e se insere na existência do indivíduo. Esta mesma tradição é o suporte histórico do Transcendente, constituído pela doutrina, pela celebração e pela ética, responsáveis pela identidade de um grupo religioso. Mudanças socioculturais podem dificultar sobremaneira o acesso a Deus mediado pela religião ${ }^{1}$.

1 "Chaque fois qu'elle abandonne un système de pensée, l'humanité s'imagine perdre Dieu” (H. DE LUBAC, Sur les chemins de Dieu, Paris, 1966, p. 207). 
Portanto, o problema do agnosticismo hodierno não diz respeito tanto a Deus quanto às representações de Deus, que agem como mediações do Transcendente. Assim sendo, o debate atual diz respeito mais concretamente ao acesso a Deus. Trata-se de uma crise que tem também um sentido positivo, a saber, apontar para uma deficiência na proclamação atual do Deus de Jesus Cristo ${ }^{2}$. Todo desafio à fé é igualmente uma oportunidade de vivê-la mais verdadeira e profundamente.

Não entraremos aqui em outra questão que trata da gênese das expressões religiosas ou das representações de Deus. Com outras palavras, o que leva o ser humano a "criar" representações do divino? Sabemos que os mestres da suspeita procuraram responder a esta questão com soluções bem diferentes umas das outras, que acabam por se destruir mutuamente. Nosso objetivo é outro. O atual debate sobre o acesso a Deus não estaria a indicar a necessidade de nos adentrarmos por outras vias, não novas ou inéditas, já que vigentes em outras épocas, mas simplesmente esquecidas ou desvalorizadas? Não racionalizamos demasiado o Deus de Jesus Cristo fragilizando assim sua pessoa e sua ação em proporção direta com o questionamento atual sobre o alcance da razão humana?

Sem desconhecer que a problemática é ampla e complexa, pretendemos tão somente oferecer algumas reflexões que possam ajudar-nos a melhor pensá-la. Começaremos examinando algumas razões que possibilitam certa atitude agnóstica por parte de muitos com relação à fé em Deus. Depois examinaremos a fragmentação moderna da razão e o consequente pluralismo como desafio a um acesso a Deus. Em seguida, numa terceira parte veremos a necessidade urgente de ultrapassarmos os dualismos hoje vigentes e recuperarmos a concepção unitária do ser humano e da história. Também aqui se nos impõe tanto valorizar o mistério de Deus quanto a teologia apofática, itens esquecidos ou marginalizados no cristianismo. Deste modo abordaremos a parte final deste texto indicando uma via mais existencial para se chegar a Deus, que começa a ser mais considerada pela Igreja atual.

\section{A temática sobre Deus como problema}

A reação de K. Barth à teologia liberal atingiu também as representações de Deus levando-o a afirmar sua absoluta transcendência, caracterizandoo como o "totalmente Outro". Mesmo o acesso a Deus através da metafísica não respeitava esta alteridade já que aprisionava Deus numa onto-teologia

\footnotetext{
${ }^{2}$ T.M. STEEMAN, "Atheism as Religious Crisis Phenomenon. A Reflexion on the Nature of the Problem”, Social Compass 24 (1977) 311-321.
} 
conforme a crítica de Heidegger. Ainda recentemente se busca pensar Deus até sem o ser para que não esteja submisso às nossas categorias mentais ou aos nossos conceitos linguísticos ${ }^{3}$. Devemos reconhecer o acerto da crítica por parte de uma teologia negativa ao pretender desmascarar as representações de Deus como sendo o próprio Deus. Mas romper completamente a relação do mundo com Deus, considerando-o como um Deus completamente isolado do nosso mundo, seria bani-lo para fora da sociedade, da cultura, da história, da linguagem, da experiência humana, como se deu no deísmo filosófico ${ }^{4}$, indo na contramão do que afirmam as grandes religiões e impossibilitando qualquer expressão sobre Deus, mesmo a analógica ${ }^{5}$.

Não nos resta outra possibilidade de acesso a Deus a não ser através da realidade criada e, de modo especial, do próprio ser humano. Em toda teologia está inevitavelmente embutida uma antropo-logia. Sempre serão possíveis projeções humanas na identidade de Deus, daí o valor da advertência apofática. Contudo podemos pensar toda a realidade tendo sua realização plena em Deus e, neste caso, a nostalgia humana por felicidade manifesta o rasto de Deus na existência histórica de cada pessoa ${ }^{6}$. Deus permanece mistério para nós, mas não mais se situa completamente fora da história humana. Esta afirmação terá seu ponto mais alto na encarnação do Verbo de Deus.

Portanto, ao respeitar o dado tradicional da incompreensibilidade de Deus (DS 800 e 3001), devemos mostrar também que Ele não nos é completamente desconhecido. A experiência da contingência de toda a realidade indica a ausência de razão suficiente na própria realidade. Toda ela aponta então para o que a chamou à existência ${ }^{7}$. Toda ela se distingue do que a explica, mas igualmente toda ela está voltada para o que a explica. $\mathrm{O}$ vocábulo "Deus", tão empregado nas religiões, apenas diz que Ele é aquele sem o qual nada existe. Ele está subjacente às causas naturais, aos eventos históricos, à hipótese evolucionista, já que toda a realidade foi criada do nada e tem a marca da contingência ${ }^{8}$. De fato, a filosofia não trata de Deus em si, mas da relação do mundo e do ser humano para com Ele. Daí não poder afirmar sem mais serem as representações religiosas de Deus meras projeções humanas?.

\footnotetext{
${ }^{3}$ J.-L. MARION, Dieu sans l'être, Paris, 1982.

${ }^{4}$ Ver C. TAYLOR, A Secular Age, Cambridge, 2007, pp. 221-269.

${ }^{5}$ W.G. JEANROND, "Zur Hermeneutik postmoderner Öffentlichkeit: Gottesbegriff und Alterität”, in E. ARENS / H. HOPING (orgs.), Wieviel Theologie verträgt die Öffentlichkeit?, Freiburg, 2000, pp. 82-100.

${ }^{6}$ J. WERBICK, "Gott", in $L T h K^{3}$ IV, Freiburg, 2006, pp. 868s.

${ }^{7}$ S. AGOSTINHO, Confissões, X,6,9: "Interroguei a massa do universo sobre o meu Deus e ela me respondeu: não sou eu, mas foi Ele que me fez".

${ }^{8}$ P. KNAUER, "Eine Alternative zu der Begriffsbildung 'Gott als die alles bestimmende Wirklichkeit", ZKTh 124 (2002) 312-325, aqui 313s.

${ }^{9}$ W. PANNENBERG, Theologie und Philosophie, Göttingen, 1996, p. 363.
} 
Por outro lado, a metafísica clássica era consciente do perigo de "funcionalizar" a noção de Deus vendo-o como fundamento e garantia do conhecer e agir dos humanos ou como o elo supremo de uma cadeia de causas e razões ${ }^{10}$. Este Deus prisioneiro nos limites da razão, feito à nossa medida, definido por nosso ideal moral, é um Deus longínquo que não intervém na história e que acaba sendo rejeitado como inútil e supérfluo ${ }^{11}$. Ou então aparece como o Deus "tapa-buraco" que surge quando a razão ou a vontade humana capitulam diante dos enigmas da realidade e que recua na medida em que a ciência e a técnica se desenvolvem ${ }^{12}$.

Também a perspectiva antropológica que compreende o ser humano como alguém aberto a toda a realidade, sempre a superá-la e a transcendê-la, com novas questões e indagações, desejos e anseios, determinando assim sua experiência do mundo e identificando-o como um ser inquieto, constitui a base de sua vida religiosa e daquilo que as religiões representam de Deus. A pessoa humana pressupõe em todo o seu ser e agir um estar remetida a um Outro, dela diferente porque infinito e transcendente, mesmo que não possa nomeá- $\mathrm{l}^{13}$. Não se trata propriamente de uma prova da existência de Deus, mas sim do que se conclui de uma reflexão crítica sobre uma experiência humana fundamental. Mais do que provar a existência de Deus é saber estar remetido (junto com toda a realidade) a um Outro Transcendente ${ }^{14}$. Diga-se, de passagem, que aqui temos o motivo de ser a fé uma opção "razoável" ao acolher livremente este Outro, embora continuamente tentada pela suspeita de ilusão ${ }^{15}$.

Outro obstáculo ao acesso a Deus consiste em suas representações inadequadas ou mesmo errôneas provindas do passado e ainda presentes na atual cultura. Sem dúvida alguma, para pessoas mais formadas e críticas, algumas imagens de Deus veiculadas pelos próprios cristãos constituem um impedimento à fé em Deus. Mesmo conseguindo ultrapassar as fronteiras de sua racionalidade e querendo sinceramente se defrontar com a questão do sentido último de sua existência, tais pessoas se chocam com o que os fiéis afirmam ou simplesmente imaginam de Deus (GS 19). Conhecemos a imagem amedrontadora de um Deus juiz e controlador de

\footnotetext{
${ }^{10}$ Não é o que subjaz ao "id quo maius cogitari nequit" de S. Anselmo?

${ }^{11}$ DE LUBAC, Sur les chemins de Dieu, pp. 208s.

12 K. LEHMANN, "Kirchliche Dogmatik und biblisches Gottesbild", in J. RATZINGER (org.), Die Frage nach Gott, Freiburg, 1973, pp. 122s.

${ }^{13}$ W. PANNENBERG, Was ist der Mensch? Die Anthropologie der Gegenwart im Lichte der Theologie, Göttingen, $1995^{8}$, pp. 5-13. Na mesma linha K. Rahner, que parte de uma metafísica do conhecimento e da liberdade. Ver K. RAHNER, Grundkurs des Glaubens, Freiburg, 1977, pp. 61-79, 104-113.

14 J. SPLETT, "Über die Möglichkeit, Gott heute zu denken”, in W. KERN / H.-J. POTTMEYER / M. SECKLER (orgs.), Handbuch der Fundamentaltheologie I, Tübingen, 20002, pp. 105-107.

${ }^{15}$ J. WERBICK, Essere responsabili della fede, Brescia, 2002, pp. 274s.
} 
nossas vidas, de um Deus distante e ausente do mundo próprio do deísmo, de um Deus que incita e justifica uma santa violência, de um Deus tapaburaco onde se demonstra impotente a ação humana, de um Deus que canoniza a mesmice e se opõe à mudança, de um Deus ciumento com o progresso e o desenvolvimento da humanidade, de um Deus concebido à nossa imagem e semelhança, de um Deus cuja presença só é pressentida em ocasiões de sofrimento e de desgraça. Poderíamos ainda acrescentar outras imagens que, embora sem respaldo no que de Deus nos ensinou Jesus Cristo, contudo refletem uma interpretação determinada e deformadora de gerações passadas e ainda vigente em nossos dias.

Também a Igreja em certos pronunciamentos de seus responsáveis denota, ao se defrontar com questões de cunho doutrinal ou ético, uma certeza desmedida do que seja a verdade de Deus ou a vontade de Deus, que leva nossos contemporâneos a se perguntarem de onde lhe advém tanta segurança. Naturalmente não negamos que a Igreja deva manter as representações tradicionais que mediatizam suas verdades de fé enquanto novas compreensões não consigam se justificar e impor. Não negamos também que constitui um dificílimo desafio pastoral ter que proclamar Deus para todo um auditório formado por pessoas de mentalidade tão plural e tão diversa. Não negamos ainda que os mais simples entre os cristãos possam ter, através de expressões ingênuas, um acesso mais verdadeiro a Deus do que as reflexões profundas e subtis dos mais críticos. Mas nos perguntamos se não deveríamos ousar mais na correção das imagens de Deus deformadas, considerando a sociedade secularizada onde vivemos e a crescente indiferença religiosa à nossa volta.

\section{A fragmentação da Razão e o surgimento de horizontes plurais}

Como vimos anteriormente, a razão encontra uma indicação do que denominamos Deus na medida em que percebe a contingência de toda a realidade. Há uma mútua relação na compreensão de Deus e do mundo. Se Deus não é pensado como origem de toda a realidade e esta em sua totalidade como remetida a Deus, o vocábulo "Deus" se torna uma palavra vazia $^{16}$ ou passa a ser considerado como produto de sonhos humanos. No passado, desde os pré-socráticos, a filosofia tratou de toda a realidade ou da unidade do cosmo. Atualmente, com poucas exceções, a filosofia renunciou a tal tarefa, orientando-se em sua reflexão para setores da realidade e mais precisamente para a problemática inerente ao sujeito que conhece e não tanto para a realidade conhecida ${ }^{17}$.

\footnotetext{
${ }^{16}$ LEHMANN, "Kirchliche Dogmatik und biblisches Gottesbild", pp. 133s.

${ }^{17}$ PANNENBERG, Theologie und Philosophie, pp. 15s.
} 
Consequência trágica deste estado de coisas é a enorme dificuldade de se articular um discurso sobre Deus em nossos dias. O advento e o desenvolvimento vertiginoso das ciências modernas acarreta a tentação, por parte de algumas, de assumirem a tarefa propriamente filosófica de pensar a realidade total. Realmente uma tentação, pois elas permanecem limitadas a uma ótica particular que as impede de captar e avaliar devidamente a totalidade do real. Se elas procuram fazê-lo então não mais se comportam como uma ciência determinada, com objetivos e linguagens próprias, mas se aventuram a fazer filosofia e má filosofia como presenciamos em algumas publicações recentes que se caracterizam tanto pela publicidade da mídia quanto pela fragilidade da argumentação. Aqui já poderíamos questionar se o conceito científico de causalidade é o mesmo que se emprega na filosofia, ou se a verdade funcional própria das ciências corresponde à verdade buscada pela filosofia ${ }^{18}$.

Estas distinções já nos indicam que o que denominamos Razão se apresenta hoje bastante diversificada em sua compreensão por parte das várias ciências. De fato, dispomos na atualidade de múltiplas formas de racionalidade que buscam conhecer e interpretar a realidade. Procuremos compreender as razões para este autodiferenciar-se da razão moderna ${ }^{19}$. Primeiramente do ponto de vista teórico. A Razão emerge já como razão filosófica quando os gregos buscam o início (arqué) de tudo. Aí a razão se caracteriza pela sua abertura transcendental ao Ser e pela sua total reflexibilidade em si mesma, que lhe permite uma unidade analógica na pluralidade de suas formas e de seus usos. Pois a razão filosófica era como a forma paradigmática à qual se referiam as demais formas. Esta estrutura analógica se rompeu nos tempos modernos e nenhuma das racionalidades atuais (físico-matemática, dialética, lógico-linguística, fenomenológica, hermenêutica) consegue, apesar de pretendê-lo, unificar o campo da Razão.

Do ponto de vista histórico a autodiferenciação da Razão se deu primeiramente na Grécia antiga, como aparece na tríplice divisão efetuada por Aristóteles em saber teorético, prático e poético, que perdurou até a Idade Média sem mudança notável. Um segundo momento desta diversificação da Razão corresponde aos tempos modernos, embora devido a outras causas. A primeira delas diz respeito ao método que estabelece regras para a construção do modelo matemático mais adequado para a explicação dos fenômenos da natureza. A razão moderna busca assim um conhecimento que procede por hipóteses e deduções e por verificação experimental, dando

\footnotetext{
${ }^{18}$ WERBICK, Essere responsabili della fede, pp. $255 \mathrm{~s}$.

${ }^{19} \mathrm{O}$ que se segue deve muito ao texto de H.Cl. DE LIMA VAZ, "Ética e razão moderna", in M.L. MARCÍLIO / E.L. RAMOS (orgs.), Ética na virada do século, São Paulo, 1997, pp. $53-86$.
} 
origem à ciência de tipo empírico-formal. Este "conhecimento é exercido metodicamente como uma operação capaz de construir o seu próprio objeto e de instituir assim uma homologia entre o sujeito e seu mundo de objetos, esses assumindo a estrutura típica de objeto técnico" ${ }^{20}$. A segunda concerne ao próprio sujeito que conhece. Diverso do sujeito da antiguidade clássica ele se caracteriza pela atividade essencialmente construtora do seu conhecer.

O espaço da razão moderna, em suas diversas formas, se define pela correlação entre a razão construtora do sujeito e pela inteligibilidade construída do objeto. A validez do conhecimento está limitada por esta correlação, como já estabelecera Kant em sua Crítica da Razão Pura. Deste modo desaparece a Razão em sua relação transcendental ao Ser, proclama-se a superação da metafísica e se perde a unidade analógica da Razão. Simultaneamente assistimos a um desenvolvimento espantoso das racionalidades modernas pela fecundidade do método empregado. O conhecimento da realidade só pode se dar através da racionalidade empírico-formal, única forma válida de conhecimento científico dos fenômenos. Estes últimos não permitem que se vá além deles e se chegue à realidade inteligível em si. Este pressuposto subjaz às diversas formas de racionalidades presentes em nossos dias, influenciando mesmo as ciências humanas caracterizadas mais como ciências hermenêuticas.

Há, portanto, uma distinção entre Razão e racionalidade. A primeira é universal, a segunda particular. A Razão diz respeito ao sujeito capaz de usá-la, sujeito racional, e à realidade por ele captada e explicada, a realidade racional. Seu conhecimento parte de princípios e obedece às regras de demonstração. Racionalidade significa estilos distintos no uso da Razão, diferenciados pelas características do objeto e do método adequado para explicá-lo. Racionalidades são as figuras da Razão, que ocupam o espaço do conhecimento racional. Assim temos a racionalidade físico-matemática, a tecnológica, a econômica, a política, a histórica, a sociológica, a psicológica, a ambiental, para citar algumas. Como a Razão está voltada para o Ser, nosso conhecimento busca sempre esta universalidade. Já as diversas racionalidades participam de forma peculiar e particular, devido a seus objetos, da Razão em sua forma universal ${ }^{21}$.

Em nossos dias a racionalidade-matriz é a racionalidade lógico-matemática, forma universal da razão científica e instrumento mais apto a satisfazer às exigências de rigor e exatidão do conhecimento e de sua expressão. As demais racionalidades giram ao redor deste polo. Deste modo a metafísica se reduz a um sítio arqueológico e as demais racionalidades são avaliadas

${ }^{20}$ LIMA VAZ, "Ética e razão moderna", p. 63.

${ }^{21}$ Ibid., p. 67. 
pela maior ou menor proximidade a este modelo. A começar pela racionalidade empírico-formal que é própria das ciências da natureza e tem na Física seu paradigma fundamental. Ela "constrói" seu objeto, o objeto técnico, o qual passa a ser considerado como o que é realmente "objetivo" para nossos contemporâneos.

Em seguida pela racionalidade hermenêutica que é própria do campo da cultura (história, sociedade, linguagem, educação, religião...) e que se desenvolve na tensão provocada pelo atrativo da racionalidade empíricoformal e pela atenção a ser dada à herança recebida das representações tradicionais do homem. A própria racionalidade filosófica atualmente se organiza em torno do polo lógico em detrimento do polo metafísico. Deste modo ela se ocupa primeiramente consigo mesma: método, estrutura epistemológica, limites do seu discurso. Diante da hegemonia da razão tecnológica ora se apresenta como uma filosofia das ciências, ora pretende ser uma racionalidade alternativa de tipo fenomenológico, existencial, hermenêutico ou crítico $^{22}$.

Uma determinada racionalidade incide inevitavelmente na pessoa humana. Pois esta sempre que exercita sua inteligência no conhecimento e sua vontade em atos livres o faz necessariamente no interior de um horizonte. Este significa um modo de olhar concreto, uma perspectiva que orienta a atenção, uma intencionalidade que dita o que nos parece real e interessante. Aprendemos sempre dentro deste campo visual. Nele nossas afirmações, nossos objetivos, nossas justificações ganham sentido. Nele devem se ajustar cada novo conhecimento ou cada nova atitude que abraçamos. Consequentemente o que está fora de nosso horizonte é considerado inexistente ou simplesmente indigno de interesse da nossa parte.

O horizonte se assemelha, em sua triagem de conhecimentos, fatos e problemáticas, ao mesmo papel desempenhado pela cultura, realidade mais abrangente e mais complexa, a qual inclui crenças, artes, costumes, hábitos adquiridos. Deste modo ela nos fornece identidade, plasma nossas estruturas mentais, configura nossa afetividade e nos capacita a interpretar a vida. Age como um mapa, uma peneira ou uma matriz ${ }^{23}$. O horizonte também se assemelha (embora também se distinga) ao que subjetivamente poderíamos denominar consciência ${ }^{24}$. Assim a consciência da criança se

\footnotetext{
${ }^{22}$ Ibid., pp. $73 \mathrm{~s}$.

${ }^{23}$ C. GEERTZ, A Interpretação das culturas, Rio de Janeiro, 1989, p. 14.

${ }^{24}$ Esta temática, embora com variações, tem recebido maior atenção recentemente. Ver H. LEGRAND, "La legitimité d'une pluralité des 'formes de pensée' (Denkformen) en théologie catholique", in F. BOUSQUET (org.), La responsabilité des théologiens. Mélanges offerts à Joseph Doré, Paris, 2002, pp. 685-704 e J.K. VOISS, "Thought Forms and Theological Constructs", in L. BOEVE / H. GEYBELS / S. VAN DER BOSSCHE (orgs.), Encountering Transcendence, Leuven, 2005, pp. 241-256.
} 
limita ao que é experimentado, enquanto a do adulto já passa por uma interpretação ou explicação da realidade; também a consciência proveniente do sentido comum difere da consciência própria das ciências; igualmente a consciência religiosa do teólogo não é a mesma do místico. Podemos mesmo encontrá-las, justapostas numa mesma pessoa, o que pode gerar até uma nova consciência ${ }^{25}$.

Normalmente percebemos a limitação do nosso horizonte como inadequado para dar resposta a todas as questões vitais. Assim nos abrimos para completá-lo com o aporte de outros horizontes. Também passamos por vários horizontes ao longo da vida conforme a idade e os conhecimentos que adquirimos. Deste modo certa evolução e crescimento pertence à autobiografia de cada um de nós ${ }^{26}$. Porém um horizonte pode não ser complementado, desenvolvido ou ampliado por outros, pois pode também simplesmente tornar o outro horizonte, ininteligível, falso ou mau. Daí sua rejeição parcial ou total do outro horizonte visto como ilusão, ignorância ou má vontade. Aqui reside, sem dúvida, a dificuldade maior em aceitar Deus para muitos que vivem no meio acadêmico.

Só podemos nos liberar (e mesmo assim parcialmente) das limitações impostas por nosso horizonte aos nossos conhecimentos ou às nossas opções na medida em que conseguirmos ultrapassar suas barreiras. Este difícil procedimento pode implicar uma reviravolta em nossa maneira de encarar a realidade, em nossa hierarquia de valores, em nossas opções futuras. Podemos considerá-lo uma autêntica conversão, que pode ser de cunho intelectual (implica nova interpretação da realidade), de cunho moral (implica nova escala de valores) e de cunho religioso (implica nova postura diante do Transcendente $)^{27}$. A questão principal aqui não é tanto a necessidade e a importância da conversão quanto o fator que poderá desencadeá-la.

Já vimos como a questão de Deus implica necessariamente a indagação pela totalidade da realidade. Nenhuma racionalidade particular consegue enquadrar adequadamente em sua perspectiva toda a realidade. Mesmo que julgue fazê-lo estará deformando a própria realidade que pensa conhecer ou estará emitindo juízos falsos sobre a mesma. Neste erro caíram não só os mestres da suspeita, mas também continuam incidindo muitos científicos em nossos dias. O desafio é deveras difícil: como fazer para que possam enxergar para além de sua própria racionalidade, alargando sua estrutura mental ou sua consciência profissional? Já conhecemos por experiência como é difícil no interior de uma Universidade traduzir na prática o tão apregoado diálogo interdisciplinar, o qual exige este transcender o seu próprio horizonte.

\footnotetext{
${ }^{25}$ B. LONERGAN, Doctrinal Pluralism, Milwaukee, 1971, pp. 12-22.

${ }^{26}$ B. LONERGAN, Method in Theology, New York, 1972, pp. 235-237.

${ }^{27}$ Ibid., pp. 237-244.
} 
Podemos adiantar aqui o que virá desenvolvido mais tarde. O ser humano, embora situado sempre no interior de um determinado horizonte, acaba por se perguntar pelo sentido último de sua existência. Pois toma consciência de que através do exercício de sua liberdade está a construir sua própria autobiografia e a constituir sua própria pessoa histórica. O seu agir livre, contudo, não se limita ao interior de sua racionalidade, exigindo dele pelo menos uma atitude de abertura, não necessariamente de aceitação ingênua, com relação aos outros campos do saber com suas linguagens e práticas específicas. Pois só posso interpretar com responsabilidade minha existência se o faço no horizonte de toda a realidade. Interpretá-la e vivêla. Por outro lado, o Transcendente é aquele ao qual se encontra remetida toda a realidade. Logo, construir sua vida de modo consciente e responsável implica vivê-la numa relação inevitável com o Transcendente. A compreensão do ser humano não pode prescindir de sua compreensão do Transcendente. Assim a conversão intelectual desencadeia a conversão moral que, por sua vez, acaba por fazer emergir em toda a sua força a conversão religiosa.

\section{Recuperar a unidade perdida e a teologia apofática}

Uma oposição entre o exercício da razão e a opção da fé, tal como presenciamos em muitos meios acadêmicos, resultou, sobretudo, de incidentes históricos do passado quando representações religiosas tradicionais se viram questionadas pelas conclusões das nascentes ciências naturais. Como a compreensão dos dados da fé cristã acontece inevitavelmente no interior de um horizonte de conhecimento, com a mudança de horizonte se problematiza o dado tranquilamente aceito no passado, com a exigência de uma nova representação da fé, tarefa nada fácil por sua complexidade e pela reação que provoca. Fenômeno análogo acontece hoje com o desafio da inculturação da fé em culturas não ocidentais.

De qualquer modo razão e fé ou, mais especificamente, filosofia e teologia, andaram sempre juntas, complementando-se mutuamente. A filosofia nasce entre os gregos como uma reflexão crítica sobre a tradição religiosa, sem a qual não chegaria à plena consciência de si mesma. Pois ao indagar pela causa da totalidade do cosmo em sua unidade, questionava a pluralidade dos deuses demasiado antropomorfos invocados nas religiões. Só um único Deus poderia ter dado origem à unidade do cosmo. O que se deu no início da reflexão filosófica vai se manifestar claramente séculos mais tarde com o advento da historicidade da razão. Daí a afirmação de Hegel de que compete à filosofia "trazer para o conceito" a tradição religiosa recebida. Igualmente o Deus do judaísmo e do cristianismo, confessado como autor de toda a realidade, como único criador, terá dificuldade em ser acolhido por adeptos de outras religiões, mas se verá confirmado pela crítica filosó- 
fica do politeísmo popular, embora nem todas as correntes filosóficas estejam igualmente próximas à confissão monoteísta judaico-cristã atestada na Bíblia ${ }^{28}$.

Este dado histórico continua válido até nossos dias. Razão e fé não são tão estranhas uma a outra como pode parecer à primeira vista. A razão filosófica continua a ser estimulada por problemáticas iluminadas pela fé, como a questão do mal, do sofrimento, do sentido, da morte, expandindo assim o horizonte filosófico para além de si próprio como aconteceu com o conceito de pessoa, de liberdade ou do sentido da história, como apontava repetidamente a Encíclica Fides et Ratio $^{29}$. Quando a razão busca se liberar de todo o capital simbólico, sempre presente mesmo quando combatido e criticado, ela perde sua referência simbólica, se encerra no campo fechado da imanência, se compraz na crítica negativa, no jogo da desconstrução sem fim, no relativismo cultural, e aponta no horizonte para o niilismo destruidor ${ }^{30}$.

Também a fé não pode prescindir da razão, por ser uma opção livre, uma opção racional e consciente de seu ato ${ }^{31}$. E a teologia enquanto busca sempre mais compreender o que crê e espera, também goza de um procedimento racional e crítico. A razão é princípio constitutivo e intrínseco à fé e à teologia. Assim filosofia e teologia guardam sua autonomia própria cada uma em seu âmbito. Contudo, elas não só se ajudam, como se necessitam mutuamente. Sem esta ação mútua também a teologia poderia cair facilmente no fideísmo e no fundamentalismo.

Esta temática goza de grande atualidade em nossos dias. Uma razão que se posicione impermeável à fé deixa sem resposta as questões vitais postas pelo ser humano sobre sua própria existência, vácuo este que tenderá a ser satisfeito por crenças irracionais de todo gênero ou por religiosidades de forte teor emotivo, que denunciam a vontade de crer numa sociedade que procura banir Deus de seu seio.

Naturalmente a concepção metafísica de Deus como Aquele ao qual está remetida toda a realidade pode entrar em tensão com o Deus da revelação presente e atuante na vida e na pessoa de Jesus Cristo. Este fato acontece quando as categorias da razão procuram enquadrar Deus dentro de sua lógica. A última palavra e a chave de interpretação deve ter a revelação. Então sua onipotência é vista como a onipotência do amor, sua eternidade como redenção do tempo efêmero condenado a desaparecer, sua

\footnotetext{
${ }^{28}$ PANNENBERG, Theologie und Philosophie, pp. 12-15.

${ }^{29}$ M. SECKLER, "Vernunft und Glaube, Philosophie und Theologie", Theologische Quartalschrift 184 (2004) 77-91, aqui 83s.

${ }^{30}$ P. VALADIER, Un philosophe peut-il croire?, Ed. Cécile Defaut, 2005, p. 32.

31 JOÃO PAULO II, Encíclica Fides et Ratio, n. 43.
} 
imutabilidade como fidelidade a si e aos seus fiéis, sua transcendência sobre a dimensão espacial como capacidade de estar junto a todos que acolhem a ação do seu Espírito, sua ausência total de qualquer necessidade como liberdade criadora capaz de começar algo novo e levá-lo a cabo, sua sabedoria e bondade infinitas como características do agir divino que levam os seres humanos à própria verdade e bondade ${ }^{32}$.

Do que vimos até aqui, por razões diversas embora conexas entre si, como o pluralismo cultural, o desenvolvimento das ciências modernas, a crise do pensamento metafísico, a virada antropocêntrica da filosofia, a concentração epistemológica, a sociedade consumista e hedonista, todos estes fatores tornaram a proclamação de Deus um sério problema em nossos dias. Deus continua o mesmo, mas está silenciado por carecermos de sinais, imagens, conceitos ou categorias que o façam experimentado e invocado por nossos contemporâneos. Daí a indiferença religiosa, o ateísmo prático, o agnosticismo por parte de muitos ${ }^{33}$.

Creio que este desafio oferece ao cristianismo um corretivo a seu modo habitual de expressar a fé em Deus. Pois estas expressões são sempre históricas, contextualizadas, configuradas a uma época e, portanto, limitadas e sujeitas a aperfeiçoamentos. Já o Concílio Vaticano II reconhece no próprio ateísmo, examinado em suas raízes, um possível fator de purificação da fé (GS 21). Contudo, este mesmo Concílio não chegou a mencionar nesta questão a importância de uma compreensão da fé bastante presente na reflexão teológica do cristianismo durante muitos séculos, conhecida como a teologia negativa ou apofática. Consciente do mistério de Deus, que ultrapassa qualquer conceito, expressão ou imagem, a tradição cunhou a formulação "docta ignorantia", empregada por Agostinho, Boaventura e Nicolau de Cusa. Santo Tomás de Aquino afirma que de Deus nada sabemos quem seja e como seja. A própria metafísica clássica percebia seus limites, embora não os tenha devidamente valorizado no ensino da Escolástica. Note-se também que houve uma mudança de acento nesta questão com relação aos dados bíblicos: o Deus escondido é considerado como o Deus incompreensível. O mistério de Deus já não é mais visto numa perspectiva histórico-salvífica, mas nos quadros de um mistério infinito inalcançável a qualquer conhecimento humano.

De qualquer modo, a filosofia moderna radicalizou esta questão ao negar a possibilidade de abarcar o Absoluto no conceito, embora reconheça uma abertura no ser humano, ainda que ambígua e imprecisa. Para alguns se trata de uma "docta ignorantia" ainda mais radical do que a da filosofia

\footnotetext{
32 J. WERBICK, "Gott", LThK IV, p. 867.

${ }^{33}$ Naturalmente o problema já vem de longa data e resulta de outras causas aqui não mencionadas, como comprova a obra de Charles Taylor anteriormente mencionada.
} 
clássica, que conduz não a um teísmo natural, mas a uma abertura últi$\mathrm{ma}^{34}$. A razão deixa assim espaço para a fé, não provando diretamente, mas remetendo indiretamente o ser humano para Deus.

É importante observar que a revelação de Deus não desvenda o mistério de Deus, mas o confirma. Assim nas manifestações de Deus este demonstra sua presença através de sinais como a sarça ardente (Ex 3,2), a coluna de nuvem (Ex 13,21), trovão e raio (Ex 19,9.16). Daqui se entende a proibição das imagens (Ex 20,4), pois para a época a divindade estava presente na imagem, o que contradizia a revelação de Javé. Nem o nome de Deus deveria ser pronunciado, pois saber o nome significava ter poder sobre a divindade. Daqui se entende também que Deus não se deixe nomear ou objetivar, mas se manifeste como autêntico poder na ação salvífica de acompanhar seu povo ao longo da história, demonstrando assim sua fidelidade e sua verdade juntamente com sua liberdade soberana.

Igualmente a gênese do que poderíamos chamar de "representação bíblica" de Deus nos mostra uma pluralidade de características provindas do contexto histórico respectivo: míticas, sincretistas, proféticas, cananeias, sapienciais, utilizadas para configurar de certo modo o Deus experimentado pelo povo de Israel e distingui-lo dos demais ${ }^{35}$. Este fato vem demonstrar que a imagem bíblica de Deus respeita sua transcendência. Também em Jesus Cristo revelador do Pai (Jo 14,9) Deus não se submete à lógica humana (Mt 20,1-16) e se revela sub contrario na fraqueza, no escândalo e na loucura da cruz somente aos que têm fé (1Cor 1,18-31). Portanto, também em Jesus Cristo permanece a presença de Deus escondida. Ele habita em luz inacessível (1Tm 1,17), é invisível ( $\mathrm{Rm} \mathrm{1,20;} \mathrm{Cl} 1,15)$ e seus pensamentos são insondáveis (Rm 11,33).

Para a Bíblia Deus é um mistério inacessível ao ser humano, é uma liberdade absolutamente soberana, que se revela como amor sem perder sua transcendência. Ao se revelar como mistério de sua liberdade, Ele permanece escondido. A revelação é o desvelar-se do mistério de Deus como mistério. Este mistério não significa negativamente a insuficiência provisória da razão, a ser sanada posteriormente, mas positivamente o conteúdo fundamental da revelação de Deus, tal como Karl Rahner procurou mos$\operatorname{trar}^{36}$. Aquele que crê não "sabe" mais sobre Deus, mas tem plena lucidez sobre o mistério de Deus e sobre sua ignorância. Ele experimenta a atuação salvífica de Deus na história humana como autodoação divina, ou seja, como amor e como mistério (1Jo 4,8-16).

${ }^{34}$ W. KASPER, "Atheismus und Gottes Verborgenheit in theologischer Sicht", in Christlicher Glaube in moderner Gesellschaft 22, Freiburg, 1982, p. 44.

${ }^{35} \mathrm{~W}$. PANNENBERG, "Erwägungen zu einer Theologie der Religionsgeschichte", Grundfragen systematischer Theologie, Göttingen, 1967, pp. 252-295, aqui pp. 268-272.

${ }^{36}$ K. RAHNER, "Über den Begriff des Geheimnisses in der katholischen Theologie", Schriften zur Theologie IV, pp. 51-99. 
O escondimento de Deus tanto oferece espaço para o ateísmo quanto desmascara sua pretensão de combater determinada representação de Deus, tanto possibilita a atitude agnóstica quanto caracteriza a fé como opção livre do ser humano. Pois este escondimento de Deus aponta para a experiência fundamental da transcendência como interpelação indeterminada e sujeita a diversas interpretações. Tanto o que crê como o que não crê encontram-se inevitavelmente com o mistério da vida, do sentido último, do que denominamos Deus. Mas o cristão goza de uma luz, ou chave hermenêutica como se diz hoje, que the permite ir além. Deste modo será capaz de interpretar e experimentar diversa e especificamente este mistério de Deus.

\section{IV. $O$ acesso existencial a Deus}

Iniciaremos oferecendo uma fundamentação teológica que qualifica a compreensão cristã da criação em geral e do ser humano em particular. A ação de Deus "para fora" de si, que a tradição atribuía indistintamente às três pessoas trinitárias, afirmando apenas que algumas ações seriam mais próprias dessa ou daquela pessoa, deixa sem resposta a questão sobre o fundamento de tal "apropriação". Por outro lado, relacionar a vida intratrinitária de Deus com suas ações no mundo e na história não só resolve essa dificuldade, como também lança nova luz sobre o sentido do universo e da humanidade.

Ao afirmarmos ser a finalidade da criação participar da vida de Deus e se esta finalidade implica um plano salvífico, então esta participação deve ser expressa trinitariamente como participação na comunhão de vida do Filho com o Pai por intermédio do Espírito. Vejamos. O desígnio salvífico (Ef 1,3-14) que fundamenta a criação e engloba cada evento se revelou em Jesus Cristo, em sua obediência à missão do Pai. Daí o plano salvífico de Deus manifestar o Filho na obediência ao Pai vinculado às condições dadas pela criação e pela história. Deste modo, integra Deus a multiplicidade das criaturas na felicidade eterna da comunhão do Filho e do Pai. Como consequência fundamental desse desígnio divino toda criatura não é apenas meio, mas tem seu sentido enquanto intrinsecamente ordenada à manifestação do Filho na história. Cada criatura participa da finalidade salvífica do Criador. É o que examinaremos a seguir ${ }^{37}$.

Não podemos indicar um motivo para a criação fora de Deus. Ao dizer, entretanto, que Deus criou o mundo em total liberdade, para que outros pudessem participar de sua felicidade eterna, estamos afirmando que o universo é expressão do amor infinito de Deus. Deus dá a suas criaturas existência, consistência, duração, porque as quer como tais, diversas de si

${ }^{37}$ W. PANNENBERG, Systematische Theologie II, Göttingen, 1991, pp. 36-39. 
mesmo. Essa bondade divina é, primeiramente, atribuída ao Pai, como origem e fonte da criação. Porém, sabemos mais sobre isso por intermédio da pessoa de Jesus Cristo.

De fato, Jesus Cristo nos revela em sua vida, palavras e atitudes, um relacionamento peculiar com Deus, a quem invoca como seu Pai e para o qual orienta fielmente toda a sua existência. Esse relacionamento implica distinção do Pai, submissão ao Pai, obediência ao Pai, deixar-se dispor pelo Pai, abandonar-se ao Pai, reconhecê-lo como o único Deus, levar a humanidade a reconhecer sua soberania. Nele se encontra não só o relacionamento do homem Jesus diante de Deus, mas também o relacionamento do Filho eterno de Deus no interior da Trindade. Pois este relacionamento filial é simultaneamente da esfera criada e da esfera intradivina. Tudo o que afirmamos da segunda pessoa no seio da Trindade tem aqui seu fundamento. Não dispomos de outro acesso. A pessoa de Jesus revela o Filho eterno.

Esse fato, entretanto, diz ainda mais. Se o consideramos na perspectiva de Deus, podemos então afirmar que o Filho eterno de Deus, pelo fato de ser distinto do Pai, pode sair da Trindade e, conservando sua eterna atitude filial, fazer surgir a criatura capaz de reconhecer conscientemente Deus como Deus, Pai e Criador, a saber, o ser humano. E, com o ser humano, todo o mundo criado como sua própria condição de possibilidade. Desse modo, o Filho eterno de Deus não só precede a humanidade de Jesus, mas é a razão de ser desta enquanto foi criada. E o relacionamento de Jesus com o Pai tem aqui o seu fundamento. E como o Pai e o Filho existem desde toda a eternidade, também estão na criação do mundo, sendo a pessoa do Filho eterno o fundamento da humanidade de Jesus e de toda a restante criação.

Neste ponto da nossa reflexão se impõe uma importante conclusão. A humanidade de Jesus em sua vida manifesta a identidade última e a estrutura subjacente de todo ser criado. Jesus aceita Deus como seu Pai e Criador em sua existência. Ele o faz porque é homem, que sabe ser diferente de Deus e limitado. Desse modo, Jesus revela, expressando em sua história, o que constitui a identidade de qualquer ser criado: reconhecer Deus como Deus, honrá-lo como Pai e Criador. Toda a vida de Jesus Cristo foi levar seus semelhantes à mesma atitude fundamental, pondo-se totalmente a serviço do Reino de Deus. Todo ser humano tem aqui a razão última de sua existência que confere sentido e consistência a sua vida.

Esta visão da criação leva à plenitude a afirmação veterotestamentária do homem criado à "imagem de Deus" (Gn 1,26). Pois S. Paulo nos assevera ser Jesus Cristo a imagem de Deus (2Cor 4,4), e somente como "imagens de seu Filho" $(\mathrm{Rm} 8,29)$ participam os seres humanos da semelhança com Deus. O cristianismo antigo considera assim Cristo como arquétipo à imagem do qual foi criado o primeiro homem. Só a manifestação do arquétipo na encarnação e na vida de Jesus leva à perfeição a imagem de Deus em nós. Daí a importante conclusão feita pelo Concílio Vaticano II: “Cristo 
manifesta plenamente o homem ao próprio homem e lhe descobre sua altíssima vocação" (GS 22). A compreensão cristã do ser humano o considera como alguém estruturalmente voltado para Deus, à semelhança de Jesus Cristo. Este fato atinge todos os seres humanos e antecede qualquer adesão ou recusa de cunho religioso.

Esta nossa reflexão não é exclusivamente filosófica, pois já sabemos até onde pode nos conduzir a razão nesta questão. Mas também não é apenas teológica, pois somente podemos tentar pensar Deus a partir da realidade criada e, sobretudo, da realidade do ser humano. Estamos na perspectiva de Santo Agostinho, cuja doutrina não admite a distinção de duas ordens, a saber, da criação entregue aos filósofos e da salvação reservada aos teólogos. Há apenas uma criação e uma economia salvífica na qual a Palavra de Deus é decisiva. Toda sabedoria humana, toda verdade tem nela sua fonte, quer dela tenhamos ou não consciência, quer a acolhamos ou não, quer sejamos crentes ou não crentes $^{38}$.

Na ordem histórica, na única ordem real, a finalidade do ser humano é vista também por Santo Tomás como participação filial na vida divina. Daí ser Deus a felicidade sem mais do ser humano ${ }^{39}$ que deseja sempre chegar à visão beatífica ${ }^{40}$. E só poderá realizar sua finalidade como ser dotado de espírito, através de sua inteligência e de sua liberdade, consciente de levar a cabo um dinamismo também presente em toda a criação (Contra Gentiles III, q. 25, 1 $)^{41}$. Esta visão unitária do ser humano está profundamente enraizada no pensamento de Santo Agostinho ${ }^{42}$ e também na concepção teológica de Santo Tomás de Aquino como procurou demonstrar Henri de Lubac em suas obras, devidamente valorizadas pelo estudo de John Milbank anteriormente citado. Não nos compete realizar aqui todo um questionamento a certa escolástica com seu dualismo entre natureza e graça, nem examinar criticamente os impasses por ela gerados. O Concílio Vaticano II nos indica ser esta mais uma página virada na história da teologia cristã (GS 34).

Permanece, contudo, a dificuldade de se relacionar a questão pelo sentido de toda a realidade e, consequentemente, de sua existência, posto pela razão humana, com a sede de participar da vida de Deus, ou de ver a Deus, na terminologia de Santo Tomás. Como se relaciona uma exigência de cunho intelectual com um desejo de ordem mística? Henri de Lubac interpreta Santo Tomás afirmando que o ser humano não se dá por satisfeito em conhecer sua dependência total do Mistério inalcançável, mas que

${ }^{38}$ G. MADEC, Le Dieu d'Augustin, Paris, 2000, pp. 160-162.

39 "Tota hominum salus [...] in Deo est" $(S . T h$. I,1,1).

40 "Toda inteligência naturalmente deseja a visão da substância divina" (Contra Gentiles II, 57).

${ }^{41}$ J. MILBANK, Le Milieu suspendu, Paris, 2007, pp. 57s, 125s.

42 "Fizeste-nos para Ti, Deus, e o nosso coração está inquieto enquanto não repousa em Ti” (Conf. I,1). 
busca conhecê-lo não de qualquer modo, mas em si, a saber, por sua essência ${ }^{43}$. E o teólogo francês se pergunta se subjacente ao desejo de saber não se encontra já um dinamismo anagógico, sem que Santo Tomás tenha conseguido unificá-los plenamente. Pois o élan místico se distingue da busca filosófica em sua raiz, em seu termo e em seu processo. Mas como se trata da mesma pessoa dotada de espírito, a razão ao se deparar com sua limitação e insuficiência, experimenta a nostalgia da fonte, desabrochando-se no dinamismo da mística e realizando assim toda sua potencialidade e sua vocação última ${ }^{44}$. O que não significa dissolver o Mistério e objetivar o Transcendente, pois nunca o alcançaremos a nosso modo.

Ele está presente sem ser visto, é encontrado quando ainda o buscamos. "Além de todas as práticas convencionais, na rejeição de toda mentira, na perda de toda segurança, através de todas as negações, no desmoronar de todas as certezas, no abandono de todo ser, descobrir Deus"45. Deus conserva sua transcendência, pois não é uma realidade que pudesse ser objeto do conhecimento e da vontade humana, mas uma realidade que desencadeia um dinamismo na inteligência e na liberdade para mais conhecê-lo e desejá-lo ${ }^{46}$. Este dinamismo vai ser experimentado, entendido, avaliado e querido ou não, através de explanações, de tematizações, de representações condicionadas historicamente e que podem ser incompletas ou erradas, exigindo aperfeiçoamentos e correções. A busca nunca se detém, pois a Deus se encontra buscando-o sempre ${ }^{47}$.

A consciência de fé deste início de milênio apresenta diversas características que, sem pretender ser inéditas, marcam o imaginário cristão atual. Não resultam de argumentações rigorosas, mas se impõem como impressões compartilhadas. Uma delas aponta na história do cristianismo para uma demasiada racionalização da fé, que se distinguia da linguagem bíblica mais dirigida ao coração ${ }^{48}$. Naturalmente a formulação correta das verdades cristãs era justificada nas diversas épocas devido às ameaças de erros e heresias, mas se viu certamente agravada pela utilização da filoso-

${ }^{43}$ S. TOMÁS DE AQUINO, Compendium Theologiae, c. CIV.

${ }^{44}$ DE LUBAC, Sur les chemins de Dieu, pp. 173-179.

${ }^{45}$ Ibid., p. 201.

${ }^{46}$ B. LONERGAN, "Natural Knowledge of God", in W.F.J. RYAN / B.J. TYRRELL (orgs.), A Second Collection, Philadelphia, 1975, pp. 117-131, aqui p. 123.

${ }^{47}$ DE LUBAC, Sur les chemins de Dieu, p. 195. Em nota o autor traz um belo texto de São Gregório de Nissa: “...cujus inventio est ipsum semper quaerere. Non enim aliud est quaerere, et aliud invenire: sed exquirendi lucrum est ipsum quaerere" (PG XLIV, 720 C). Textos semelhantes em Santo Agostinho, ver MADEC, Le Dieu d'Augustin, pp. 92s, $114,166$.

${ }^{48}$ Um teólogo norte-americano já observou que a cultura ocidental moderna é responsável pela separação entre pensamento e sentimento, teoria e prática, forma e conteúdo. Ver D. TRACY, "Traditions of Spiritual Practice and the Practice of Theology", Theology Today 55 (1998) 235-241, aqui p. 235. 
fia aristotélica. Com isto a síntese feliz da era patrística na qual a experiência e o conceito caminhavam juntos acaba por se desfazer ${ }^{49}$.

Observemos ainda que a nostalgia de Deus nasce do coração, do núcleo central da pessoa humana, no qual as faculdades ainda se encontram unidas. Tanto a afetividade como a liberdade desempenham importante papel no conhecimento humano. A ação de Deus como Mistério atinge a totalidade da pessoa em seu coração, iluminando-a com sua luz e consolando-a com sua paz, mesmo que esta não consiga traduzir esta ação em conceitos que fariam de Deus mais um objeto de conhecimento. Observemos também que nesta perspectiva a presença atuante de Deus se faz sentir em meio às experiências humanas, cotidianas ou não. Importante é saber captar esta presença escondida, vislumbrada nas entrelinhas do texto de nossa vida.

Diante da atual dificuldade de um discurso sobre Deus pela fragmentação cultural e filosófica e diante da tentação de uma solução emotiva ou fundamentalista nos perguntamos se não se impõe valorizar mais a via existencial para Deus, que não deveria ser monopólio dos místicos, mas patrimônio de todo o povo cristão ${ }^{50}$. Sabemos que a verdade de Deus na Bíblia não se constitui tanto através de arrazoados quanto de uma experiência diuturna de fidelidade (emet), de consistência, de firmeza, de amor. A verdade bíblica não prescinde da história, mas nela acontece, se realiza e se manifesta como tal. Naturalmente esta concepção não exclui a noção grega de verdade ${ }^{51}$. Levando devidamente a sério seja o que nos revela Jesus Cristo de Deus, seja a verdade última sobre o ser humano, nos perguntamos pelas suas consequências em relação a um adequado anúncio de Deus para nossos contemporâneos.

Sem renunciar ao que exige nossa razão para não cairmos em desvios fatais como já se deu na história do cristianismo, julgamos, entretanto, que a via existencial que valoriza a experiência pessoal do Mistério de Deus na vida de cada um deveria ser mais enfatizada. É o amor e somente o amor que leva a razão a se ultrapassar a si mesma, pois ele tem razões que a própria razão desconhece. Teoricamente nossa fé se encontra continuamente ameaçada por sempre novos "mestres da suspeita". Existencialmente, contudo, ela nos convence, confirma, ilumina com sua própria luz e com a experiência pessoal de cada um com Deus. Uma luz e uma verdade que nos acompanham, evoluem, mudam, progridem, simplificam-se atra-

\footnotetext{
${ }^{49}$ H. URS VON BALTHASAR, La Gloire et la Croix, Paris, 1965, pp. 185-360.

${ }^{50}$ Daqui a importância e a atualidade da tese de H. DE NORONHA GALVÃO, Die existentielle Gotteserkenntnis bei Augustin. Eine hermeneutische Lektüre der Confessiones, Einsiedeln, 1981, assumindo a perspectiva existencial para o acesso a Deus (p. 16), que implica a totalidade da pessoa livre (p. 20) num processo da "scientia" para a "sapientia" que não acontece sem uma autêntica conversão.

${ }^{51}$ M. DE FRANÇA MIRANDA, "Verdade cristã e pluralismo religioso", in ID., A Igreja numa sociedade fragmentada, S. Paulo, 2006, pp. 305-312.
} 
vés das provações e das purificações tornando-nos mais firmes, mais livres, mais passivos diante do Mistério que nos acompanha e que é o que temos de mais íntimo.

O Concílio Vaticano II reconhece que na "gênese do ateísmo grande parte podem ter os fiéis, enquanto, negligenciando a educação da fé, ou por uma exposição falaz da doutrina, ou por faltas em sua vida religiosa, moral e social, se poderia dizer deles que mais escondem do que manifestam a face genuína de Deus e da religião" (GS 19). Aqui já aparece como a questão sobre Deus não pode ser reduzida apenas ao âmbito da razão já que atinge toda a realidade do ser humano. O testemunho de uma existência, vivida à luz de Deus, é decisiva para mostrar Deus como Alguém que irrompe na história pessoal de homens e mulheres deixando emergir assim sua verdade e sua realidade. A repercussão que obteve em todo o planeta o testemunho de vida da Madre Teresa de Calcutá comprova o que afirmamos.

A Igreja como "sacramento da salvação universal" para toda a humanidade não só realiza o que ela é através de sua proclamação da Palavra de Deus, mas também por meio do testemunho de vida de seus membros. Este ponto é deveras muito importante para a fé em Deus por parte de muitos dos nossos contemporâneos, mesmo daqueles que labutam no meio acadêmico. Nunca pecaremos por valorizá-lo. Se apenas o mencionamos é devido ao objetivo mais limitado desta nossa reflexão.

Por isso mesmo a proclamação de Deus por parte da Igreja não pode prescindir do testemunho pessoal. A soberania de Deus (Reino de Deus) se faz presente e atuante por meio dos que vivem os valores deste Reino. Esta é, no fundo, a finalidade última da comunidade eclesial: deixar transparecer a ação salvífica de Deus em Jesus Cristo ao longo da história. A crise de fé em nossos dias não deixa de ser também uma interpelação à Igreja para que configure sua realidade institucional e oriente sua pastoral para uma autêntica mistagogia. O coração da comunidade de fé está na mística, na comunhão com o Deus vivo e entre si por parte de seus membros. Neste sentido entendemos as palavras de Henri de Lubac: "os santos são entre nós as testemunhas eficazes de Deus" ${ }^{\prime 52}$.

Quando vemos as diferenças abissais entre ricos e pobres que atravessam tanto nosso planeta como nossos países, quando constatamos a indiferença religiosa grassando entre os que mais possuem e mais consomem, quando vemos crescer a insensibilidade diante do sofrimento alheio por parte dos que desfrutam melhor situação social, quando ouvimos de bispos, sacerdotes, religiosos/as e leigos/as que a imersão entre os mais pobres significou um autêntico encontro com o Deus vivo, então compreendemos não só serem eles os que melhor captam a salvação de Jesus Cristo ${ }^{53}$, "os desti-

\footnotetext{
${ }^{52}$ DE LUBAC, Sur les chemins de Dieu, p. 185.

${ }^{53}$ SAGRADA CONGREGAÇÃO PARA A DOUTRINA DA FÉ, Instrução sobre a liberdade cristã e a libertação, n. 22 .
} 
natários privilegiados do Evangelho" ${ }^{\prime 54}$, os que vivem com simplicidade os valores evangélicos da solidariedade e da partilha, mas também os que apresentam e expressam "um intenso sentido da transcendência, uma capacidade espontânea de se apoiar em Deus e uma verdadeira experiência do amor teologal" 55 . "Quantas vezes os pobres e os que sofrem nos evangelizam realmente!"56

Reconhecemos a importância da razão para o cristianismo, tão presente já em seus primeiros anos de vida; reconhecemos a necessidade de uma ordem jurídica para a sobrevivência de qualquer comunidade humana e, portanto, também da Igreja; reconhecemos o dever do magistério eclesiástico em zelar pela doutrina e pela moral cristã; reconhecemos o papel imprescindível das instituições eclesiásticas para a continuidade da vivência da fé. Mas nos perguntamos se a atual sociedade (e também a Igreja) não se assemelha àquela que encontrou Paulo em Corinto, escandalizada com o modo de ser e de agir de Deus. "O que é loucura no mundo, Deus o escolheu para confundir os sábios; o que é fraco no mundo, Deus o escolheu para confundir o que é forte; aquilo que no mundo é vil e desprezado, aquilo que não é, Deus o escolheu para reduzir a nada o que é" (1Cor 1,27s). Pelo fato de Cristo se ter feito pobre para nos salvar (2Cor 8,9), "o encontro com ele nos pobres é uma dimensão constitutiva da nossa fé" ${ }^{\prime 57}$ e os necessitados são o lugar onde podemos encontrá-lo (Mt 25,31-46). Podemos acrescentar ainda que hoje, mais do que nunca, esta verdade é o critério da autêntica mística cristã. Ou o acesso que buscávamos ao mistério de Deus que nos envolve e é o único capaz de nos dar a tão ansiada felicidade plena. Acesso este que não pode ser sistematizado ou domesticado em nossos conceitos, mas que esclarece as questões fundamentais da vida humana ${ }^{58}$.

Mario de França Miranda SJ é doutor em teologia pela Pontifícia Universidade Gregoriana (Roma). Atualmente é professor de teologia sistemática na Pontifícia Universidade Católica (Rio de Janeiro). Publicou entre muitos livros e artigos: Um catolicismo desafiado: Igreja e pluralismo religioso no Brasil, São Paulo: Paulinas, 1996; O cristianismo face às religiões, São Paulo: Loyola, 1998; A salvação de Jesus Cristo: A doutrina da graça, São Paulo: Loyola, 2004; A Igreja numa sociedade fragmentada, São Paulo: Loyola, 2006; e Aparecida: a hora da América Latina, São Paulo: Paulinas, 2007.

Endereço: R. Marquês de São Vicente, 389 22451-041 Rio de Janeiro - RJ e-mail: mfranca@puc-rio.br

${ }^{54}$ CELAM, Documento de Aparecida, n. 550.

${ }^{55}$ Ibid., n. 263.

${ }^{56}$ Ibid., n. 257.

${ }^{57}$ Ibid.

${ }^{58}$ NORONHA GALVÃO, Die existentielle Gotteserkenntnis bei Augustin, p. 291. 


\section{COLEÇÃO BÍBLICA LOYOLA}

A Coleção Bíblica Loyola, sob responsabilidade da Faculdade Jesuíta de Filosofia e Teologia de Belo Horizonte, publica estudos, comentários e subsídios bíblicos de nível científico internacional, seja traduzidos, seja produzidos por biblistas nacionais.

\section{TÍTULOS MAIS RECENTES:}

19. As duas fases da pregação de Paulo (M. Pesce)

20. O Evangelho de Mateus e o judaísmo formativo (J. A. Overman)

21. A Bíblia na Igreja (J. A. Fitzmyer)

22. O pensamento do templo - de Jerusalém a Qumran (F. Schmidt)

23. As formas literárias do Novo Testamento (K. Berger)

24. Procurais o Jesus histórico? (R. Zuurmond)

25. Sabedoria e sábios em Israel (J. Vílchez Líndez)

26. Mulher e homem em Paulo (N. Baumert)

27. A evolução do pensamento paulino (U. Schnelle)

28. Metodologia do Antigo Testamento (H. Simian-Yofre [org.])

29. A mensagem do Reino (R. A. Horsley e N. A. Silberman)

30. Abraão e sua lenda: Gênesis 12,1-25,11 (W. Vogels)

31. Israel e seu Deus: (F. Gradl e F. J. Stendebach)

32. Sacrifício e culto no Israel do Antigo Testamento (Ina Willi-Plein)

33. O Jesus Histórico: um manual (Gerd Theissen / Annete Merz)

34. A Tríade: fé, esperança e amor em Paulo (Thomas Söding)

35. A Primeira história do Cristianismo (Daniel Marguerat)

36. Introdução ao Antigo Testamento (Erich Zenger et al.)

37. Introdução à leitura do Pentateuco (Jean-Louis Ska)

38. A "fórmula da aliança" (Rolf Rendtorff)

39. As parábolas de Jesus em Marcos e Mateus (Michel Gourgues)

40. A invenção de Cristo (Maurice Sachot)

41. As origens da Bíblia (John W. Miller)

42. Naquele tempo... Concepções e práticas do tempo (M. Gourgues e M. Talbot)

43. Introdução à exegese do Novo Testamento (U. Schnelle)

44. A encarnação do Filho de Deus (Ulrich B. Müller)

45. Sinopse dos Evangelhos de Mateus, Marcos e Lucas e da "Fonte Q" (J. Konings)

46. Entre os dois Testamentos. História e religião na época do Segundo Templo (J. Maier)

47. As parábolas de Lucas (Michel Gourgues)

48. Religião de visionários: apocalíptica e misticismo no cristianismo primitivo (P.A. de S. Nogueira)

49. O homem bíblico. Leituras do Primeiro Testamento (A. Wénin)

50. Aquele que manda a chuva na face da terra (C.M. Dias da Silva)

51. Davi e sua história ( $W$. Vogels)

52. A Bíblia grega dos Setenta - Do judaísmo ao cristianismo antigo (M. Harl, G. Dorival, O. Munnich)

53. O Messias (H.-J. Fabry / K. Scholtissek)

54. Os milagres de Jesus - Perspectivas metodológicas plurais (Rafael Aguirre)

Edições Loyola - Cx. P. 42.355 - CEP 04299-970 São Paulo

e-mail: vendas@loyola.com.br 